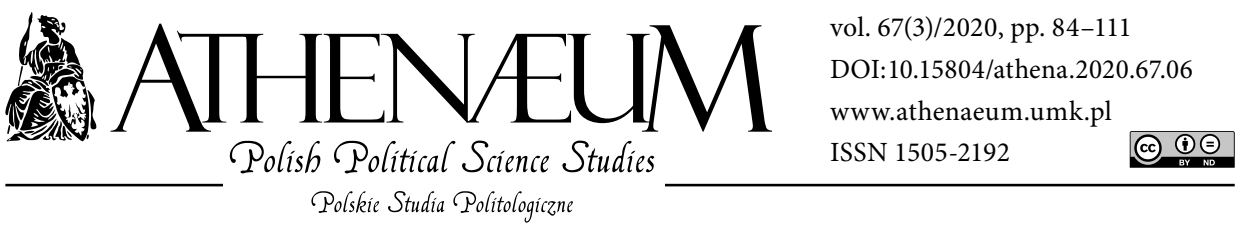

\title{
SPECIFICS OF THE SO-CALLED ISLAMIC STATE
}

\author{
SPECYFIKA TZW. PAŃSTWA ISLAMSKIEGO
}

Kinga Smoleń*

\begin{abstract}
The aim of this paper is to analyze the specific character of the so-called Islamic State. For the purposes of the study it is based on two assumptions. Firstly, the rise of the so-called Islamic State was determined by a number of regional and international conditions, in particular the destabilization of the Middle Eastern order, the events of the Arab Spring, operations of the United States in the region, globalization processes, and technological development. Secondly, the specific nature of the so-called Islamic State, reflected in the use of violence and intimidation, noncompliance with the principles of international law, and challenging the international order exclude the possibility of the entity in question being considered as a person of international law. To begin, with view to attain the research objective stated above and under consideration of the research hypotheses adopted herein, this paper examines the root causes behind the rise of the so-called Islamic State at the regional and international level. Subsequently, it defines the specific nature
\end{abstract}

\section{ABSTRAKT}

Celem poznawczym artykułu jest analiza specyfiki tzw. Państwa Islamskiego. Dla potrzeb podjętego problemu przyjęto dwa założenia. Po pierwsze, na powstanie tzw. Państwa Islamskiego wpłynął szereg uwarunkowań o charakterze regionalnym i międzynarodowym, m.in.: destabilizacja porządku na Bliskim Wschodzie na skutek wydarzeń Arabskiej Wiosny Ludów, działania Stanów Zjednoczonych w regionie, procesy globalizacji i rozwój technologii. Po drugie, specyfika tzw. Państwa Islamskiego określana m.in. przez: stosowanie przemocy, zastraszanie ludności, nieprzestrzeganie zasad prawa międzynarodowego oraz kontestowanie porządku międzynarodowego - nie pozwala uznać go za podmiot prawa międzynarodowego. $\mathrm{W}$ ramach artykułu wskazane zostaną, po pierwsze, najważniejsze uwarunkowania powstania tzw. Państwa Islamskiego na poziomie regionalnym i międzynarodowym. Po drugie, określona zostanie specyfika badanego podmiotu z uwzględnieniem zasięgu przestrzennego,

* Maria Curie-Skłodowska University, Faculty of Political Science and Journalism. 
of the entity in question, taking into account its territory, internal structure, principles of operation, and personality.

Keywords: so-called Islamic State; terrorist organization; Middle East; state; quasi-state struktury wewnętrznej i zasad funkcjonowania oraz podmiotowości.

Słowa kluczowe: tzw. Państwo Islamskie; organizacja terrorystyczna; Bliski Wschód; państwo; quasi-państwo

The so-called Islamic State declared its establishment in June 2014, thus confirming the significance of the late Westphalian international relations. These are characterized by pluralism and hybridity of subjective and objective scope as well as an increasing complexity (Pietraś, 2015). The specific nature of the so-called Islamic State regarded as a new participant of international relations is subject to several factors. Firstly, its legal personality is unregulated. Secondly, its structure and functioning are based on violence and terror. Thirdly, its territory is merely declared and not confirmed by any international treaties. Due to these factors and because it does not comply with the principles of international law but rather clearly defies the international order, the so-called Islamic State cannot be considered a state. It should be noted that international relations scholars are not unanimous in the classification of the entity in question. There are two major approaches described in the literature, whereby the so-called Islamic State is considered either as a terrorist organization or as a quasi-state.

The aim of this paper is to analyze the specific character of the so-called Islamic State. The analysis serves to summarize the existing research, as well as to organize the knowledge about the new entity in the international system. For the purposes of the study, it is based on two assumptions. Firstly, the rise of the so-called Islamic State was determined by a number of regional and international conditions, in particular the destabilization of the Middle Eastern order, the events of the Arab Spring, operations of the United States in the region, globalization processes, and technological development. Secondly, the specific nature of the so-called Islamic State, reflected in the use of violence and intimidation, noncompliance with the principles of international law, and challenging the international order exclude the possibility of the entity in question being considered as a person of international law.

The following research methods and techniques were used in the publication. Factor analysis was used to examine the regional and international determinants of the emergence of the so-called Islamic State. The analysis of statistical data was 
used to determine the extent of the area occupied by the so-called Islamic State, as well as its military and financial resources. The analysis of the state of literature and research was used to verify and evaluate studies on the functioning of the so-called Islamic State, and also helped to define the level and state of research of the analyzed phenomenon.

To begin, with view to attain the research objective stated above and under consideration of the research hypotheses adopted herein, this paper examines the root causes behind the rise of the so-called Islamic State at the regional and international level. Subsequently, it defines the specific nature of the entity in question, taking into account its territory, internal structure, principles of operation, and personality. The analysis covers the period 2014-2018, in which the so-called Islamic State occupied certain areas. Since the statehood of the Islamic State is disputed, it shall be referred to as the so-called Islamic State.

Among the popular science studies, a significant contribution to the study of a new participant in the international system, which is the so-called Islamic State, can be found in the following monographs: A.B. Atwan, Islamic State: The Digital Caliphate, London 2015; P. Cockburn, Państwo Islamskie [The Jihadis Return], Warszawa 2015; B. Hall, ISIS Państwo Islamskie. Brutalne początki armii terrorystów [Inside ISIS: The Brutal Rise of a Terrorist Army], Warszawa 2015; M. Weiss, \& H. Hassan, Wewnatrz armii terroru, Warszawa 2015. Articles in scientific journals should also be considered valuable, among others: D. Holbrook, $A l$ Qaeda and the Rise of ISIS, „Survival. Global Politics and Strategy” 2015, vol. 57; J. Dobbins, \& S.G. Jones, The End of a Caliphate, „Survival. Global Politics and Strategy" 2017, vol. 59; H. Brands, \& P. Feaver, Was the Rise of ISIS Inevitable?, „Survival. Global Politics and Strategy” 2017, vol. 59. Among the Polish studies, attention should be paid to the Amicus Europae Foundation study entitled Wojna $z$ Kalifatem edited by I. Bil, J. Gajda, \& T. Otłowski, published in 2015 in Warsaw, as well as articles, among others: S. Wojciechowski, Fenomen „Państwa Islamskiego" i jego źródła, „Przegląd Strategiczny” 2016, vol. 9, and K. Wojtasik, Życie codzienne na terenach tzw. Państwa Islamskiego w przekazie jego oficjalnych mediów, „Media i Społeczeństwo” 2016, vol. 6. From 2018, the so-called Islamic State is analyzed in an increasing number of Polish-language scientific studies: B. Bolechów, Słowa w cieniu mieczy: „Dabiq” i narracja Państwa Islamskiego, Wrocław 2020; M. Dziekan, K. Zdulski, \& R. Bania, Arabska wiosna i świat arabski u progu XXI wieku, Łódź 2020; M. El Ghamari, Cool Jihad, Warszawa 2018; A. Graban, \& M. Jaroszyńska, Działalność propagandowo-informacyjna Daesh, Warszawa 2018; A. Wejkszner, Samotne wilki kalifatu? Państwo Islamskie 
i indywidualny terroryzm dżihadystyczny w Europie Zachodniej, Warszawa 2018. The studies mentioned above were used in the article.

\section{DETERMINANTS OF THE RISE OF THE SO-CALLED ISLAMIC STATE}

The so-called Islamic State came into existence owing to various regional and international determinants (Brands \& Feaver, 2017, pp. 7-54; Warrick, 2017). Among the regional factors, it is primarily the Arab Spring that was of the greatest significance (Ilkowski, 2011), whereas the international factors include the actions of the United States in the Middle East, globalization processes, and technological development.

\section{Conditions at the regional level}

The underlying cause of the events of the Arab Spring were high food prices. According to World Bank data, they increased by 15 percent (Ilkowski, 2011) from November 2010 to January 2011. The event which directly sparked the radicalization of social unrest in the Middle East was the self-immolation of Mohamed Bouazizi, a Tunisian street vendor. Initially, this tragedy gave rise to a wave of nationwide protests, as a result of which President Zine Ben Ali was forced to resign (Kaczmarek, 2014). This led very quickly to social tensions in other states of the region, i.e., Egypt, Yemen, Libya, Syria, Bahrain, Saudi Arabia, Jordan, Morocco, and Oman. Citizens organized street protests by means of modern tools of communication, including mobile phones and social networking sites.

A political analysis of the Arab Spring events should take into consideration the diverse nature of its effects (Smoleń, 2020). A part of them further deepen the instability in the Middle East (Dziekan, Zdulski, \& Bania, 2020; Ożarowski \& Grabowski, 2017) and as such must be deemed explicitly negative. These consequences include: the dysfunctionality of some countries, in particular Syria, Iraq, and Libya (Gil, 2015); local problems which remain unsolved; uncontrolled mass migration and thus the issue of refugees; increasing Islamization of social life; as well as radicalization of groups with an Islamic background. At the same time, the influence of liberal-democratic, leftist and nationalist movements declined (Dołgow, 2014).

The Arab Spring proved most tragic for Libya and Syria. In the case of the former, the events contributed to a government change. Those who fought the 
regime of Muammar Gaddafi received support from a coalition of Western countries. Before long, the conflict evolved into a regular civil war, as a consequence of which the situation developed into a dual-power arrangement. Since 2011, the capital is ruled by the National Transitional Council, which was established with the aid of the European Union and the United Nations. The parliament, in turn, is located in Tobruk and remains under the control of the army. While the conflict persisted, the so-called Islamic State began its operation in Libya.

Syria, next to Libya, is recognized as one of the most dysfunctional countries of the international system as a result of the events of the Arab Spring (Fragile State Index, 2015). It has been categorized as one of states labeled High Alert in the Fragile State Index. Based on an analysis of trends over the years 2006-2015, Syria ranked second as to increasing dysfunctionality. One of the relevant factors which drove Syrians to the streets and made them demand a change of the existing authorities (Ilkowski, 2014) was the drought they were experiencing over the years 2006-2010. As its effects were not addressed by the government, nearly 1.5 million inhabitants of villages migrated into cities. This process permanently changed the socio-economic structure of the country (Sawiński, 2014). At the beginning of 2012, anti-government demonstrations turned into an armed resistance movement, leading to the death of 7,000 people (Olszanecka, 2012). The government forces used increasingly violent methods to quell the opposition, and as a result social unrest evolved into a bloody civil war.

Although the international community has taken several peace initiatives, a permanent solution to end the conflict in Syria has not been found. The two main factors which contribute to its complexity are ethnic and religious divisions within Syria which preclude any common coalition from being created (Michalik, 2014) ${ }^{1}$, as well as external entities involved in the conflict, whose interests and political ambitions are mutually exclusive, thus diminishing the possibility of a single coherent strategy being developed (Rojek, 2014) ${ }^{2}$. Deep

\footnotetext{
1 A representative of the Alevi Islamic community (constituting 10 percent of the Syrian population), President Bashar Al-Assad has the support of Christians and the Druze, the Baath Party and the government security forces. The opposition comprises the Sunni population, i.e., the 70 percent of the society. The symmetric division among the followers of various denominations of Islam has naturally become a sphere for the expansion of the Wahhabis, i.e., Muslim fundamentalists from Saudi Arabia. The internal situation in the country is furthermore complicated by the presence of both Sunnis and Kurds.

2 The Syrian authorities have the support of Lebanon, Iran, Russia, and China, as well as Hezbollah as a non-state actor, whereas the opposition is supported by Saudi Arabia, Qatar, the Republic of Turkey, the United States, and the European Union.
} 
ethnic and religious divisions and dysfunctional state structures enabled fighters of the so-called Islamic State to occupy a part of Syrian territory.

\section{Conditions on the international level}

Following the attacks of September 11,2001, the US administration labeled Iraq as a part of the group of countries supporting international terrorism dubbed the axis of evil on the basis of the reports whereby Iraq was developing weapons of mass destruction. As a result of this decision, the United Kingdom and the United States attacked Iraq in March 2003 (Kubiak, 2005). The fundament of US foreign policy was the idea of the so-called conservative internationalism, reflected in unilateral activities, various types of political and military instruments, as well as in a moral interpretation of actions taken (Jarczewska-Romaniuk, 2005). Although the regime of Saddam Hussein was overthrown in April 2003 and he himself was captured eight months later, the war in Iraq was not over. Patrols of the coalition forces were regularly attacked by armed rebel groups. Despite the first free elections to the Parliament in 2005 and the establishment of the Government, the situation has not improved (Iraq - Conflict..., 2012).

2006 saw a deterioration in the Sunni-Shiite relations in Iraq. In August 2010 , the US army withdrew from the Iraqi territory, with 35 to 50 thousand soldiers remaining until December 2011 for the purpose of supporting the Iraqi government and security forces (Bocheńska, 2011). The final removal of American troops from the territory destabilized country even further. The part of the population which was excluded from social life after the US soldiers had been deployed now turned to even more radical steps. These were primarily military and civilian groups of Hussein's Sunni allies. It is the marginalization of that group that led directly to the creation of the so-called Islamic State (Hodali \& Metzner, 2014).

As a result, a part of former allies and distant associates of the toppled dictator began to form a united front against the US army. Under the leadership of Abu Musab al-Zarqawi, "al-Qaeda in Iraq" (AQI) came into being. Upon his assassination in 2006, local leaders formed an alliance between al-Qaeda in Iraq and another terrorist structure called "Mujahideen Shura Council", ultimately leading to the creation of a new organization: "Islamic State in Iraq" (ISI) (Hodali \& Metzner, 2014). In 2010, Abu Bakr al-Baghdadi took command of this organization, after the tragic death of its former leader, Abu Omar al-Baghdadi (Cockburn, 2015). By sending fighters into war-torn Syria, al-Baghdadi contributed to 
the establishment of the terrorist al-Nusra Front with bases in Raqqa, Idlib, Deir ez-Zor, and Aleppo.

In April 2013, al-Baghdadi decided to combine the "Islamic State in Iraq" and the al-Nusra front into one organization named "Islamic State of Iraq and Levant". The objective of the new entity was to centralize the terrorist groups operating on the territories of Iraq and Syria (Cockburn, 2015). The merge never happened as the leader of the al-Nusra Front, Abu Mohammad al-Julani, opposed it. This is interpreted as a sign of struggle for supremacy and leadership among radical Islamic terrorist organizations. Al-Julani pursued to introduce the al-Nusra front into al-Qaeda structures. Thanks to his efforts, the Front received the status of the official representative of al-Qaeda in Syria. At the same time, the leader of alQaeda, Ayman al-Zawahiri, ordered all Salafi organizations that operate in Syria to acknowledge the al-Nusra Front as their superior. In response, al-Baghdadi detached itself completely from al-Qaeda and started to compete with it for influence on the border of Iraq and Syria (Cockburn, 2015). Regardless of this failure, on June 29,2014, al-Baghdadi declared the establishment of a caliphate under the name of the "Islamic State", led by himself. The caliphate must be regarded as a self-proclaimed state because it has not been acknowledged by most fundamentalist organizations, whereas its existence is disputed by leaders of Muslim countries and numerous preachers (Cockburn, 2015).

It should be stressed that the escalation of tensions and social unrest comprising the Arab Spring and leading to the creation of the so-called Islamic State were only possible owing to globalization and dynamic technological development. The essence of globalization processes has become the topic of many debates and consequently various dimensions of this phenomenon are emphasized. It is most frequently identified with system determinants which exhibit novel characteristics that affect the parameters of the international order. The essence of the new quality of social life and the functioning of the transnational space is well defined by the mechanism of the "time-space compression", whereby, as explained by the British geographer David Harvey, the compression of time and space experienced nowadays manifests itself in shorter time and smaller space (Harvey, 1989).

The phenomenon described above is contingent upon the dynamics of the technological development. As a result of this mechanism, social phenomena and processes undergo deterritorialization, and thus a transnational social space is being formed and functioning. The notion of deterritorialization regarded as a factor behind a quality change in the international environment should mean 
that the globalization processes lead to the establishment of interaction and ties not from a distance, "across" the territory, but rather at no distance, relatively detached from a particular location (Scholte, 1996). The crux of the matter lies in the low importance of geographical distance and space in its traditional meaning. The local and the global issues are mutually conditioning. The awareness of the world as a whole, as a "single community" or "one place", is gradually increasing.

The technological factor plays a key role in isolating the transnational space where a wide variety of social interactions could occur, regardless of national borders (Rosenau \& Singh, 2002; Mueller, 2010; Kremer \& Müller, 2014). The first modern information revolution, initiated in the middle of the nineteenth century, focused above all on different communication methods, and it allowed people to utilize the telegraph, the telephone, and the radio. The second information revolution led to the spread of $\mathrm{TV}$, satellites and early generations of computers. These inventions revolutionized the way people communicate and, what is relevant in the context of the evolution of the transnational space, they have changed the importance of distance, time, and location. However, the structure of the international system remained unchanged (Surmacz, 2015). The dynamic development of technology reflected in unprecedented technological innovativeness induces substantial changes in the organization and functioning of social life, such as reorganization of the world economy, evolution of political processes, or new methods of communication and transport (Kellner, 1998). The trends presented above are apparent in the events of the Arab Spring and the emergence of the so-called Islamic State.

\section{ESSENCE OF THE SPECIFICS OF THE SO-CALLED ISLAMIC STATE}

The specific character of the so-called Islamic State (Wasiuta, Wasiuta, \& Mazur, 2018) should be analyzed in several dimensions. Firstly, this concerns the spatial range, i.e., the area that is under the control of the examined entity. Secondly, its internal structure and rules of functioning. Thirdly, its unregulated personality 3.

3 This publication attempts at the classification of the so-called Islamic State as a new participant of international relations, whereas the issue of its irregular personality is the subject of another section. 
Specifics of the spatial range

Abu Bakr al-Baghdadi, the founder of the so-called Islamic State (Chrośnicki, 2015/2016), aimed at gaining control over an extensive area, stretching from Aleppo to Mosul (Cockburn, 2015). In spring of 2014, al-Baghdadi managed to dominate the eastern part of Syria exploiting the failure of the government, with Raqqa as the "capital" of the occupied territory (Kucharczyk, 2015). Upon securing his position in Syria, al-Baghdadi went on to conquer Iraq, governed by a relatively weak Shiite administration in a constant conflict with the Sunnis.

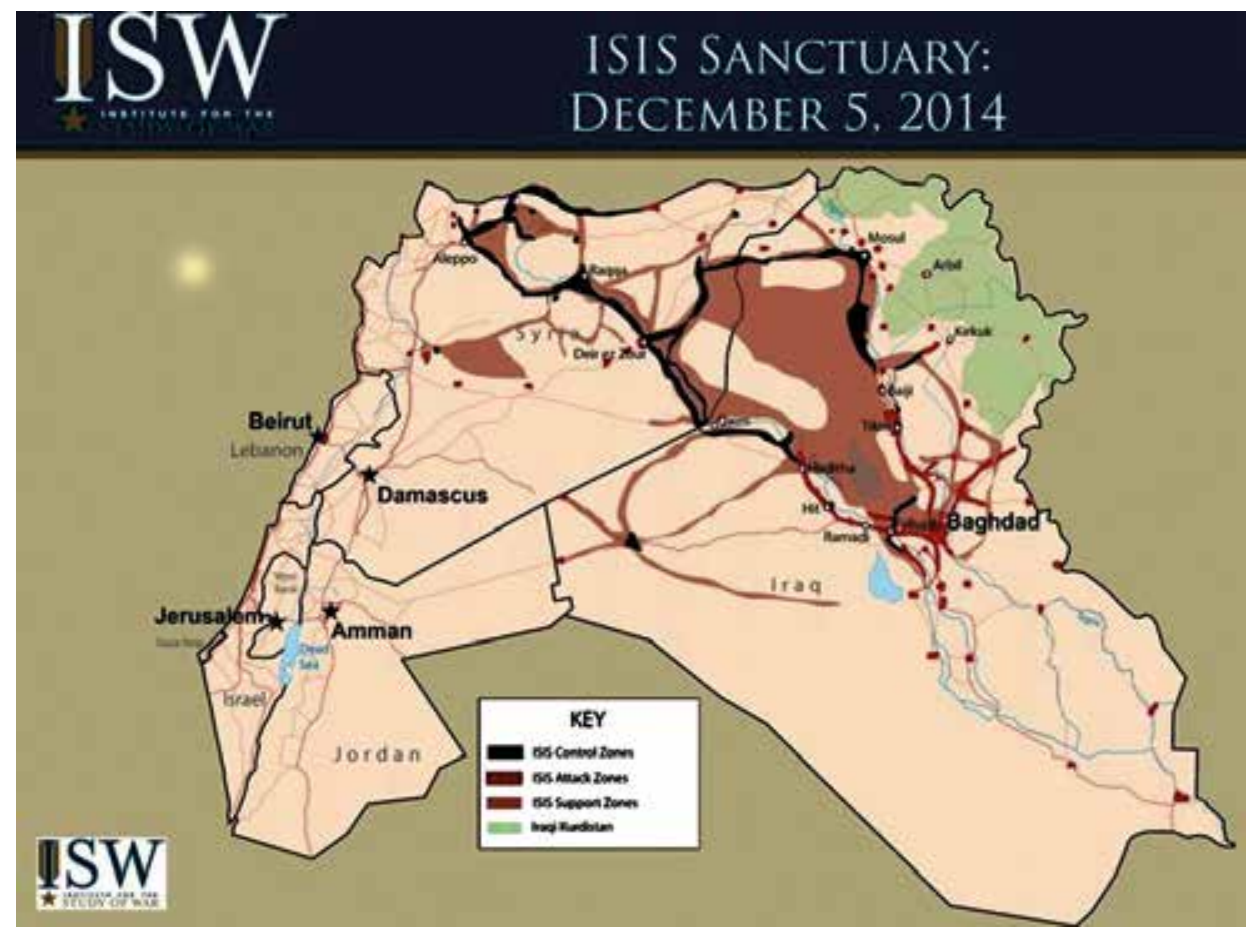

Map 1. Territory of the So-called Islamic State in December 2014

Source: Tanter, 2014, p. 2.

By September 2014, the jihadists captured Mosul, inhabited by over one million people, and almost the entire western Iraq (Kucharczyk, 2015). By the end of 2014, a significant part of western Iraq and almost all eastern Syria was under the control of the so-called Islamic State. In this period, it also commanded strong 
forces in the central part of the country, almost entirely driving out Kurdish troops and forcing them to heroically defend the city of Kobane. According to the information of the Institute for the Study of War, the jihadists occupied nearly $200,000 \mathrm{~km}^{2}$ in January 2015 (Atwan, 2015). This area was inhabited by approximately ten million people (Dobbins \& Jones, 2017). The so-called Islamic State held 19 percent of the Iraqi territory and 14 percent of Syria (Dobbins \& Jones, 2017). From the beginning of 2015, the so-called Islamic State clearly began to lose initiative. The only major jihadist offensive at the time was capturing Palmyra in May, a town controlled by the regime of Bashar al-Assad. The fighters also managed to gain access to oil and gas fields in the central regions of Syria (Kucharczyk, 2015).

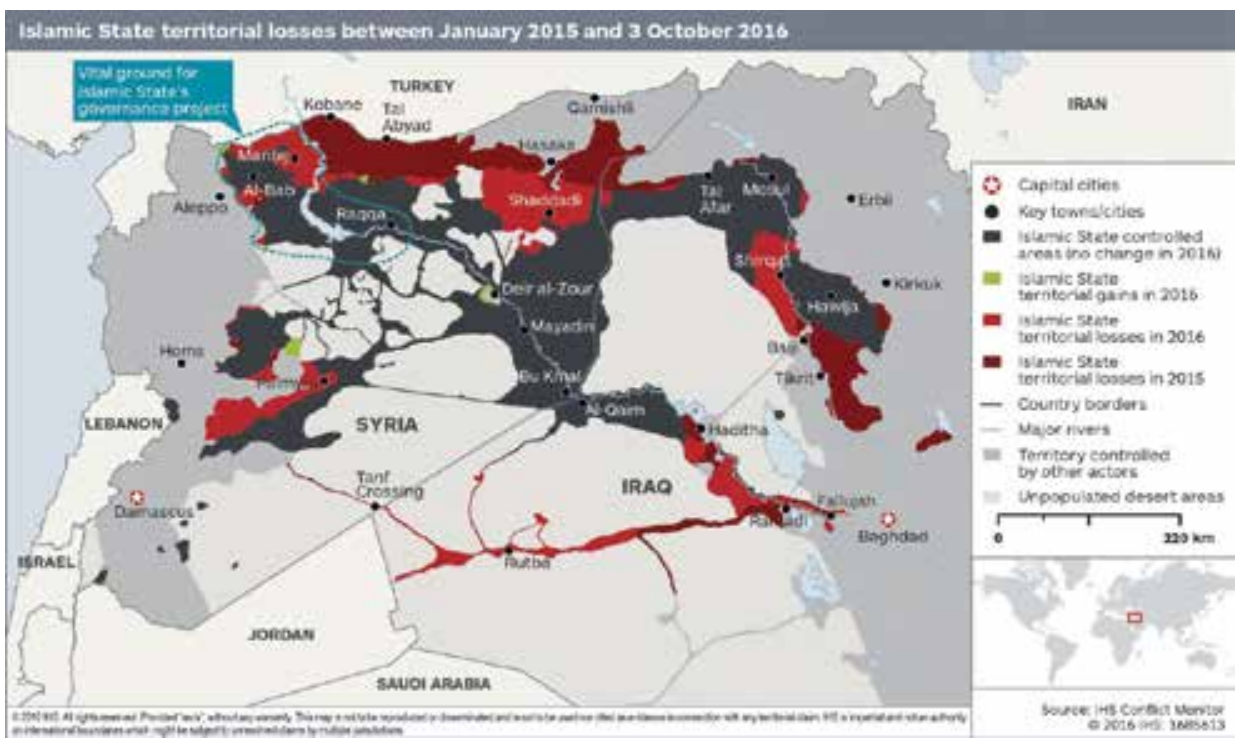

Map 2. Territory Lost by the So-called Islamic State between January 2015 and October 2016 Source: Islamic State Caliphate Shrinks by 16 Percent in 2016... (2016).

In the remaining months of 2015, the jihadists lost only the already established strategic points of their territory. In March, they were expelled from the city of Tikrit (Iraqi Forces Recapture..., 2015), whereas in October from Baiji (Iraqi Forces and Militia..., 2015). In the following year, Salafi radicals lost control over Ramadi in February (Iraq Says..., 2016), Rutba in May (Iraqi Forces Retake..., 2016), and Fallujah in June (Cockburn, 2016). October 2016 saw a large-scale 
operation of Iraqi troops. Their aim was to recapture Mosul, which was the last major urban center controlled by the so-called Islamic State. Both Sunni and Shiite militia as well as the Kurdish peshmerga fighters participated in it. The international coalition under the leadership of the United States rendered air support throughout the operation. As a result of these activities, the eastern part of Mosul was freed in January 2017. A few months later, on July 9, the Iraqi Prime Minister Haider al-Abadi announced that the city was liberated from the jihadist occupation.

According to Jane's Terrorism \& Insurgency Centre, the so-called Islamic State lost 23 percent of the area occupied by its fighters since the beginning of 2016 (Raport...,2017). This means that the territory of $78,000 \mathrm{~km}^{2}$ shrank to an area of slightly above $60,000 \mathrm{~km}^{2}$ (Raport..., 2017). In comparison to 2014 , the losses of terrorists amounted to 90 percent in 2018. However, the fact that the so-called Islamic State lost control over the vast majority of the occupied area does not mean that it has been completely overcome and is not a threat anymore. The report of the United Nations shows that there may still remain 20 to 30 thousands of Islamic State members on the territory of Syria and Iraq (State, 2019). They occupy mainly parts of the desert and not any major urban centers.

Outside the territory of Syria and Iraq, the largest activity of the so-called Islamic State was observed in Libya. After Muammar Qaddafi was shot, the state was in fact split between two competing government administrations. Given such internal instability, particularly in the south of Libya, many jihadists who earlier fought in the northern Mali moved to Libya (Czerep, 2015). Members of the local terrorist organizations, particularly the Battar Brigade, declared the establishment of the Barqa (Derna) provincial division of the Islamic State in October 2014 (Czerep, 2015). Subsequent wilayat, i.e., caliphate provinces, were created in Tripoli and Fezzan. In 2018, there were 3 to 4 thousand jihadists active in Libya. Outside the territory of Libya, the provinces subordinate to the so-called Islamic State appeared in Algeria, Niger, Nigeria, Saudi Arabia, and Afghanistan. The organization aimed at controlling these provinces in terms of infrastructure and facilities. Firstly, a significant number of the recruits came in particular from North Africa. Secondly, dependent areas, especially Derna, were the transit point for terrorists from Sudan, Syria and other areas (Czerep, 2015).

The actions of the international anti-terrorist coalition prompted the process of decentralization and division of the so-called Islamic State, and so Africa became a strategic region for the jihadists, particularly for Sahel Islamist groups. They decided to unite under the name of the Islamic State in the Greater Sahara 
(ISGS) and took fight with anti-terrorist units from Burkina Faso, Chad, Mali, Mauritania, and Niger. The experts stress that it is these countries that are particularly vulnerable to terrorist attacks. Islamist terrorism also poses a serious threat in Nigeria, Somalia, Kenya, Tanzania, and Uganda (De Maeyer, 2018).

According to the authorities of the autonomous Kurdistan, at the end of 2019 the process of rebuilding the structures of the so-called Islamic State was about to end. The terrorists are now expected to be in the Hamrin Mountains in northeastern Iraq. The Kurds estimate that the number of jihadists is around 10,000 , of which four to five thousand are to be in Iraq. After the reorganization, Daesh's goal is not to control a compact territory, but to operate underground and carry out attacks similar to Al-Qaeda $(B B C \ldots, 2019)$. The above reports can be considered credible due to the increasing number of terrorist attacks in Iraq. Attacks are also taking place in Afghanistan and Syria. The organization's revival is favored by social protests against the center of power in Iraq, as well as by the presence of Turkish troops in the north of Syria, and thus the weakening of the Kurds who have carried out very effective operations against the so-called Islamic State (Jendroszczyk, 2020).

\section{SPECIFICS OF THE STRUCTURE OF THE SO-CALLED ISLAMIC STATE}

Another factor important for the analysis of the specific character of the socalled Islamic State is its internal structure. It was supposed to pursue two objectives. Firstly, to demonstrate the power of the so-called Islamic State and thus prevent any rebellion among the occupied population. Secondly, to provide for the basic social needs of the local community and give this radical organization an impression of statehood. It should be noted that these objectives were successfully achieved for the entire period the fighters of the so-called Islamic State were occupying the parts of Syrian and Iraqi territories.

At the core of the internal structure of the so-called Islamic State is its historical background and strict interpretation of rules of the Qur'an. Since its very beginning, regardless of the probable reorganization it has recently undergone, the so-called Islamic State has been managed by the self-proclaimed caliph. Until the decentralization and the division of the so-called Islamic State, the caliph was advised by the Shura Council, an authority consisting of a dozen members selected by the caliph himself. The members of the Shura Council supervised the administration and the military, whereas the Sharia Council was responsible 
for the religion and the judiciary on the territory, as well as for overseeing the religious police (al-Hisbah). Its official competences also included the election of the caliph. The remaining relevant bodies constituting the internal structure of the so-called Islamic State are the following: the Military Council/War Office, Security and Intelligence Council, Education Council, Economic Council, Province Council, Islamic Council for Services, Ministry of Martyrs, Islamic State Institution for Public Information (Atwan, 2015). The members of these bodies were to control the compliance with the Quranic principles in their subordinate areas.

An analysis of the internal structure of the so-called Islamic State should take into account the fact that coercive measures, in particular the religious police (al-Hisbah), played a very important role in the organization right next to its administration. The propaganda messages spread by the fighters show that al-Hisbah was responsible for the safety and the protection of the local population and its possessions (Wojtasik, 2016). In practice, however, the main task of the police was to ensure that the local communities observe Muslim principles and values. Should there be any suspicion that a person browsed websites or possessed any materials related with Western values, officers could apprehend such a person and search their homes and equipment (phones, computers). If such materials were to be found, household members were subjected to severe corporal punishment, including flagellation (Hall, 2015).

As the control of the so-called Islamic State over the occupied territories was highly unstable, it required ongoing reinforcement. Numerous local clan militias proved crucial as they were put into service to the caliph by the elders of larger Sunni clans (Otłowski, 2015). The total number of members of these formations on the areas occupied by the so-called Islamic State was estimated at about 30 thousand people. Their role was in a way complimentary to the coercive apparatus of the Sunni organization. Clan militias performed law-enforcement and police tasks. They were to preserve the Islamic social order and secure the provision of basic public services, as well as to participate in local riot control operations. Clan militias were regularly supported by the army of the so-called Islamic State (Otłowski, 2015). Given the intensity and scale of the activities of the religious police and clan militias, as well as their almost unlimited power, it may be concluded that the area occupied by the so-called Islamic State was governed by principles typical of a police state (Wojtasik, 2016). 
The internal structure of the entity in question also comprises its media system $^{4}$. Its specific nature is subject to two factors: a considerable scale in comparison with other terrorist organizations, and efficiency in performing its information and propaganda, as well as recruitment functions. The major actors were and probably still are the following institutions: Al-Hayat Media Center founded in 2014, As-Sahab, Al-Furāt Media Foundation, Al-Malahem Media, Ajnad Media, and Asedaa Foundation (Wojtasik, 2016). These are specialized units consisting of high-level experts in the field of IT, graphic design, advertising and many others. Until the Islamic terrorists were ousted from Syria and Iraq, there were smaller agencies at the regional level which documented actions of jihadists in individual provinces of the so-called Islamic State. In April 2016, the media organization structure welcomed a group of hackers called the United Cyber Caliphate. The main means of communication and information for the jihadists now are probably Amaq News Agency and Halummu Website.

By means of media tools, the so-called Islamic State was able to develop a large recruitment capacity, which called for a strictly hierarchical and wellorganized army. It was deemed one of the strongest, most effective and best motivated Islamic paramilitary structures in the region of Levant by a part of analysts. The actual size of the army of the so-called Islamic State is not known. According to the most commonly cited estimates, it amounted to 20 to 50 thousand fighters at the time of the jihadi offensive (Wojciechowski, 2016), yet some reports claim that this number could be even 200 thousand, taking into account not only the regular fighters (who would indeed give a total of up to 50 thousand people), but also tribe and clan forces and special formations such as religious police. From the 200 thousand fighters, only about 15 to 25 thousand were actually trained and experienced or provided with military know-how (Otłowski, 2015).

In terms of organization, the army of the so-called Islamic State comprised different kinds of formations, such as infantry, marksmen, reconnaissance, quartermasters and others (Wojciechowski, 2016). Among the armed formations of the organization, a special position was held by Amni. This structure was responsible for intelligence, counterintelligence, and security. It was also assigned such tasks as kidnapping, assassination and other acts of terror. Amni was directly

${ }^{4}$ For the purposes of this publication, the use of the media by members of the so-called Islamic State will be subject to a thorough analysis in section titled "Specifics of the Functioning of the So-called Islamic State". 
subject to the caliph (Wojciechowski, 2016). In view of the specific nature of the abovementioned tasks, it can be assumed that Amni still exists, perhaps under a different name, regardless of the reorganization of the so-called Islamic State. According to unconfirmed reports, Amni was supposedly a major force not only due to disciplined and well-trained fighters, but also due to chemical weapons in quantities difficult to estimate (Wojciechowski, 2016).

The structure of the so-called Islamic State demonstrates a relatively high capacity as to its political, military, social, financial and logistical organization (Wojciechowski, 2016). Since these are the matters regulated by the state, the government of the so-called Islamic State confirms the efficiency of its power.

\section{SPECIFICS OF THE FUNCTIONING OF THE SO-CALLED ISLAMIC STATE}

The specific character of the so-called Islamic State as to its functioning is determined by several elements. First, brutal and violent actions aimed at continuous intimidation of the population and financial profit. Secondly, propaganda and manipulation of the media and the Internet for the purpose of ideological penetration. Thirdly, operational flexibility. Fourthly, continuous expansion of influence zone, characteristic for the first months of self-proclaimed caliphate. Fifthly, networking with other radical organizations.

The fighters of the so-called Islamic State combine physical strength with brutality never seen before in terrorist organizations, observed not only in their military actions, but also in the form of terrorist attacks and other acts of terrorism aimed at representatives of other faiths or other forms of Islam, as well as members of various ethnic and political groups (Desbois \& Nastasie, 2019). An example of this type of action was when they burned alive a Jordanian pilot trapped in a cage in 2015 or beheaded 21 Coptic Christians. To a great extent, these practices resemble medieval executions (Wojciechowski, 2016). They confirm how ruthless and unscrupulous the jihadists are. It should be noted that numerous spectacular and bloody executions were published in the media or on the Internet prior to the neutralization of the majority of their forces on the territory of Syria and Iraq. This measure was intended to demonstrate the strength and power of the so-called Islamic State on the one hand and to indicate the radicalism of the fighters on the other hand, and thus raise fear, primarily among the citizens of Western countries and infidels (Atwan, 2015). 
On the basis of these considerations it can be concluded that the so-called infidels and representatives of the Western civilization are the two main enemies targeted by the members and supporters of the entity examined. Since the proclamation of the so-called Islamic State, the jihadists have led or inspired over 30 terrorist attacks, predominantly against the Christians and followers of other non-Muslim religions. Many of them happened in the Western countries (Wejkszner, 2018). Over 650 people were killed altogether (IISS Strategic Comments, 2016). The most spectacular attacks were carried out in November 2015 in Paris (130 fatalities) (Castillo et al., 2015), in March 2016 in Brussels (32 fatalities) (Polskie MSZ..., 2016), and in May 2017 in Manchester (23 fatalities) (Manchester..., 2017).

Apart from those organized acts, attention should be called to single-handed terrorist attacks carried out by individual people inspired by the ideology of the so-called Islamic State. They are not members of the organization itself or are loosely affiliated with it. On the one hand, this specific relation between the so-called lone wolves and the jihadists is the reason why it is so difficult to locate them. The chances to thwart a bombing plot are therefore severely reduced. On the other hand, this confirms the efficiency of terrorist propaganda. Currently, it is the activity of those lone wolves that poses one of the major threats to the security of the Western European countries, as the jihadists operating within the structures of the so-called Islamic State have been weakened by the international anti-terrorist coalition and now concentrate their activities in the Middle East and Africa.

For the members of the so-called Islamic State, violence and terror generated financial profit at the time when they occupied territories of Syria and Iraq. According to the law of zakat, one of the five pillars of Islam, Muslims are required to donate up to $2.5 \%$ of their wealth on an annual basis (Godlewski, 2015). However, the tax charged must not be greater than that percentage, which is a major restriction for the jihadists. A high tax, or in fact a forced tribute, in the amount of 10 percent of total revenue was therefore imposed on infidels („Państwo Islamskie”..., 2015). In addition, they were forced to pay protection money to the fighters in return for a questionable promise of security. Should they fail to observe this order, they were subjected to severe punishment, including death. Only in 2014 did the Salafi terrorists extort 360 million dollars from the occupied civilian population („Państwo Islamskie”..., 2015). Aside from the charges described above, residents of areas occupied by the so-called Islamic State had to bear extra costs of pharmaceutical drugs (10 to 35 percent tax), 
bank cash withdrawals (5 percent), or education (22 to 65 dollars) („Państwo Islamskie"..., 2015). A high road toll of 200 to 1000 dollars was collected from drivers on the Iraqi roads („Państwo Islamskie”..., 2015).

The organization also gained certain financial benefit from human and organ trafficking, kidnapping for ransom, and blackmailing the occupied population. According to the Thomson Reuters Accelus report, 12 percent of total revenue of the so-called Islamic State in 2014 was derived from extortion, whereas 4 percent came from abductions and robberies („Państwo Islamskie”..., 2015). Another source of income of the jihadists is mass theft and looting. Upon capturing Mosul in June 2014, they stole near half a billion dollars in cash from the local banks (Godlewski, 2015). It is estimated that the members of the so-called Islamic State could have obtained up to 12 million dollars per day from the criminal activity in Mosul alone. Mass looting occurred not only in private homes, but also numerous monuments, including churches and archaeological artifacts. Some of the artifacts, situated on the territory of Syria, dated eight thousand years back and were sold for nearly 40 million dollars to collectors on the black market (Godlewski, 2015). A part of the revenue came from donors. It is estimated that approximately 20 million dollars were transferred to the account of that organization as humanitarian aid", primarily from Qatar and Kuwait (Godlewski, 2015). It is possible that such contributions from the socalled devotees still flow in.

The financial independence of the so-called Islamic State was possible thanks to sale of crude oil and natural gas obtained from deposits in Syria and northern provinces of Iraq. The profits from raw materials and energy sources quickly got to the top of the financial pyramid of the organization (Godlewski, 2015). According to Financial Times, the jihadists earned approximately 1.5 million dollars per day and 540 million dollars on a yearly basis only by selling petroleum („Państwo Islamskie”...,2015), whereas the Reuters agency estimated their income at a significantly greater amount of 730 million to nearly 1.5 billion dollars („Państwo Islamskie”..., 2015).

These considerations lead to the conclusion that no terrorist structure in the past had such possibilities of obtaining financial means or so large financial resources at its disposal as the so-called Islamic State. In 2015, the revenue of this entity was estimated at 2.4 billion dollars (Wojciechowski, 2016). In comparison, the funds of other terrorist organizations were estimated as follows: al-Qaeda with 15 to 50 million dollars, Hamas with 70 million dollars, Hezbollah 200 to 500 million dollars (Wojciechowski, 2016). Such budget largely determined the 
specific structure and principles of the functioning of the so-called Islamic State as well as defined the scale and efficiency of its operations.

An analysis of the propaganda of the so-called Islamic State must cover the specific functioning of the jihadi media system (Graban \& Jaroszyńska, 2018). One of its major functions and objectives was to provide information and propaganda about the so-called Islamic State (Bolechów, 2020). The image that was created presented a stable state with a (relatively, given the conditions of the Middle East) well-developed social welfare system, compliant with the sharia law. Its second function was tactical and operational, and namely to recruit new members (Kmiecik, 2016). A particularly effective instrument for this purpose was the Internet (Kubiński, 2018; El Ghamari, 2018), where short videos were posted, picturing the jihadist offensive and mass executions of "infidels". In the "Dabiq", "Rome" and "Dar Al-Islam" online magazines (in English and French), the jihadists explained and justified the fight with infidels referring to a very radical interpretation of the Qur'an. The so-called Islamic State is still using the Internet to recruit new members, yet the online actions of the terrorists have been limited to social networking sites, especially Facebook and Twitter. In a wider sense, the Internet constitutes an educational platform for the jihadists, used for posting a variety of training materials and instructions, for example, how to construct explosives. It is also a tool for obtaining financial profits. Users post links to websites where anyone can design a T-shirt with the Daesh ${ }^{5} \operatorname{logo}$ or order a flag and other gadgets through Facebook and Twitter groups (Kmiecik, 2016).

The offensive actions of the so-called Islamic State were particularly spectacular in the first dozen months after the self-proclaimed caliphate was established. It was possible thanks to the simultaneous use of psychological warfare (brutal media campaigns, propaganda in the social media, etc.) and tactical action based on the operational flexibility of troops (Otłowski, 2015). In terms of military actions, the so-called Islamic State focused on blitzkrieg-style of operations, attacking the enemy by deploying a mobile unit, such as a company or a battalion (Weiss \& Hassan, 2015). The aim of such an impact was to quickly capture

5 Term 'Daesh' (or Da'ish) has been used as a way of challenging the legitimacy of the group due to the negative connotations of the word. 'Daesh' is essentially an Arabic acronym formed from the initial letters of the group's previous name in Arabic - "al-Dawla al-Islamiya fil Iraq wa al-Sham". Although it does not mean anything as a word in Arabic, it sounds unpleasant and the group's supporters object to its use. 'Daesh' also sounds similar to an Arabic verb that means to tread underfoot, trample down, or crush something (Irshaid, 2015). 
a minor object (a village, town, city district, building, etc.) in order to secure and uphold it, and then resume its socio-economic functions and tasks. In the case of larger objects (e.g., a big city), the jihadists would lead a surprise attack and inflict greatest damage possible (also by taking extreme terrorist measures) and then disengage and return to their initial positions.

As a result of this strategy, the communities which chose to remain in the areas attacked by terrorists were generally characterized by religious homogeneity and willing to comply with the rules imposed by the so-called Islamic State. Should the local population resist and refuse escape, the jihadists would launch another, more fierce attack on them as a kind of "punishment" for their defiant behavior (Otłowski, 2015). When the target of an attack was a reinforced object, such as a military base or a fortified building, the jihadists would combine purely terrorist actions (suicidal attacks) with standard military operations. The attack was started by suicide bombers driving gun-equipped pick-up trucks (SVBIED) filled with explosives. The next to attack were suicide fighters with individual loads, equipped with explosive belts. Subsequently, the regular assault groups were tasked with capturing the entire object and overcoming any remaining resistance (Otłowski, 2015).

It should be emphasized that the tactics of the so-called Islamic State was based on the high mobility of its units, possible through the use of a fleet of technicals, i.e., civilian pick-up vehicles, SUVs, trucks modified for military purposes, and machinery of purely military use. Within the units, companies and battalions acted independently of the armed formations equipped with tanks and armored infantry vehicles. The above-mentioned units were often deployed on these sections of the front where it was necessary to reinforce armored units (Otłowski, 2015).

The development of a specific flexibility in terms of military operations of the so-called Islamic State directly affected the dynamics of spreading its sphere of influence, especially in the early phase of its existence. For this purpose, members of the organization developed a strategy for opening new battlefronts, which entails, among others, taking action in new countries or regions, including terrorist attacks and training. This strategy was formulated by al-Qaeda and then extended and improved by the so-called Islamic State. In the past years, it was implemented in the following countries and regions: Afghanistan, Pakistan, Chad, Cameroon, Somalia, Nigeria, Niger, Yemen, Philippines, Indonesia, Malaysia, Palestine, as well as Western Europe, the Caucasus, and the Balkans (Wojciechowski, 2016). 
Given the fact that the jihadists have limited possibilities of occupying extensive areas, it may be assumed that one of the main instruments of spreading their sphere of influence is ideological penetration. International relations research indicates that such countries as Tunisia, Lebanon, Jordan, Algeria, Saudi Arabia, Qatar and region of Mount Sinai in the Sinai Peninsula may be particularly vulnerable to the ideology of the so-called Islamic State (Cirlig, 2015). The specific character of the functioning of the so-called Islamic State should be examined for its links to other terrorist organizations. This factor significantly strengthens the entity, and at the same time fighting it becomes more complex. The most significant radical groups which have established cooperation with the members of the so-called Islamic State include: Boko Haram in Nigeria, Ansar al-Sharia in Libya and Tunisia, Ansar Bait al-Maqdis in Egypt, as well as Tehrik-i-Taliban from Pakistan (Henzel, 2014). Thus, an international terrorist network has been established.

\section{SPECIFICS OF THE INTERNATIONAL LEGAL PERSONALITY OF THE SO-CALLED ISLAMIC STATE}

The personality of the so-called Islamic State as a legal entity is not clear. Due to its common name used customarily in mass communication, the notion of it being an actual state is constantly reinforced in the public mind. There has not been a single approach in the literature which would clearly indicate of the legal personality of this new participant of international relations. From the two dominant approaches, the first classifies the so-called Islamic State as a quasistate, whereas the second one labels it as a terrorist organization.

One option that should be explicitly rejected is that the so-called Islamic State is an actual state. According to a classic definition of statehood based on a state's structural elements, the German lawyer Georg Jellinek indicates that a state possesses the following qualifications: a defined territory, a government, and a permanent population (Szmulik \& Żmigrodzki, 2002). Other frequently indicated attributes are the capacity for establishing and maintaining external relations with other countries as well as international recognition. A basic condition for the existence of a state is possessing its own territory, i.e., an area of land and space over which the sovereign state has effective control. On its territory, the government "exercises its own prerogatives considered fully and jointly in respect of individuals, objects and events" (Szmulik \& Żmigrodzki, 2002). As to 
the population criterion determining the statehood of an entity, it is not national and tribal ties that define a citizen of a state, but rather being its resident for an appropriately long time and recognizing the public authority which exercises control over a given territory (Szmulik \& Żmigrodzki, 2002).

The so-called Islamic State has never had a territory whose borders would be confirmed by international treaties. It has only held control over selected provinces of Syria and Iraq which it seized and then occupied. It should be therefore stated that the territory of the entity in question was of a merely declaratory nature. As to the state government, the so-called Islamic State was highly efficient in managing the local provinces. It appointed a political elite and established state structures, including courts, army, police, media, education system, etc. These elements confirm its actual public power within the territory it controlled. In January 2015, i.e., during the offensive of the so-called Islamic State, the areas it occupied were inhabited by nearly 10 million people. Taking into account that the population adhered to the obligations imposed on it by the jihadists, including the payment of taxes and observance of the sharia law principles, it can be concluded that it was indeed under the jurisdiction of the so-called Islamic State. However, it must be clearly stated that it was forced by the occupant to do so by means of intimidation and terror. It is therefore appropriate to exclude the possibility of the local population voluntarily acknowledging the authority of the so-called Islamic State, whereas it was recognized by members of its army. Thus, the entity in question indeed has its citizens.

While such attributes as a government and a population may substantiate the statehood of the so-called Islamic State, two others preclude it. These are namely the capacity for establishing and maintaining relations with other entities and international recognition. The first, along with the ability to enter international agreements, to be a member of international organizations, to participate in international economic trade, to extend claims against other states and participants of international relations and to pursue them seeking an amicable resolution, as well as respect for the rules of international law and the agreements concluded, responsibility for its own actions and for actions of its officials, are the conditions necessary for a participant of international relations to be regarded as a person of international law and to acquire international legal capacity. The so-called Islamic State does not meet any of them (Kondrakiewicz, 2006).

The statehood of the so-called Islamic State is also excluded on the basis of theories regarding a state's international recognition. Pursuant to the constitutive theory of state, a state must enjoy recognition of other states in order to acquire 
international legal personality. The declaratory theory, in turn, implies that an entity becomes a state at the moment it comes into existence, whereas its recognition by other states merely confirms the status quo, establishes its international status and extends its scope of powers. Given that the effects of recognition in respect of international law occur if a state meets the criteria of international law, the so-called Islamic State may not be considered a state in accordance with this theory (Antonowicz, 2015).

As the so-called State Islamic does exhibit certain attributes characteristic of a state, according to a part of the literature sources, this entity is rather associated with the notion of a quasi-state due to the following reasons. Firstly, it exercises effective control over the occupied area. Secondly, it has existed for more than two years. Thirdly, it performs the main functions of a state to a limited extent, which was to ensure a limited public support, relative internal stability, financial autonomy, and limited participation in the international trade for the so-called Islamic State until it was decentralized and its organizational structures dismantled (Gil, 2015).

From the elements presented above, two are debatable. One may agree with the claim that the so-called State Islamic exercised effective control over the occupied area, but only to the extent whereby its center of authority effectively managed the occupied provinces of Syria and Iraq. In 2018, the jihadists lost control over nearly all occupied centers, which rendered their power over them relative. Public support for the so-called Islamic State was also limited as it was forced upon the local population through the use of violence and intimidation. The entity aspiring for the category of a quasi-state should meet one more condition, and namely to actually endeavor to receive international recognition. In the case of the so-called Islamic State, this was never the case. In June 2014, Abu Bakr al-Baghdadi announced the establishment of the self-proclaimed caliphate and its declarative territory, expecting the international community to accept the new status quo.

On the basis of these considerations, the Author of the article ascertains that only certain elements characteristic for a quasi-state are applicable in respect of the so-called Islamic State, as the remaining features are only relative. It is therefore not possible to clearly label the entity in question as a quasi-state, neither are there any grounds for classifying it as a state. Given its use of violence, political motivations and objectives, as well as long-term psychological effects, it can be assumed that the so-called Islamic State is a terrorist organization (NiziołCelewicz, 2006). This analysis shows, however, that it exhibits characteristics 
attributable not only to a terrorist organization, but also to a criminal group, state, terrorist network and an armed formation. The so-called Islamic State - according to the Author - exceeds the classic understanding of a terrorist organization. It is in fact a hybrid terrorist structure and constitutes the most complex part of the so-called inverted terrorist pyramid (Wojciechowski, 2016).

In summary, this study confirms accepted assumption that the arrival of the so-called Islamic State as a new participant of international relations was determined by regional and international conditions, in particular the events of the Arab Spring, operations of the United States in the Middle East, globalization processes, and dynamic technological development. On the basis of the considerations presented above it may be stated that it is the specific nature of the functioning of the so-called Islamic State, defined primarily by the extensive use of violence and intimidation as well as reluctance to establish and maintain relations with other states and noncompliance with the principles of international law and challenging the international order that exclude the possibility of the entity in question being considered as a person of international law. The personality of the so-called Islamic State - according to the Author - is very specific and not yet clearly defined. Over the years 2014-2017, it was a highly complex hybrid terrorist structure characterized by elements typical of a classic terrorist organization, terrorist network, criminal group, armed formation, and a state. No other terrorist structure in the history of international relations has ever had such a significant hard power reflected in military equipment or zealous fighters. Neither has any other terrorist structure ever applied soft power instruments to such an extent, especially in respect of propaganda on the Internet and in other media.

\section{SUMMARY}

Due to the specific nature of the functioning of the so-called Islamic State, defined above all by the extensive use of violence and intimidation as well as reluctance to establish and maintain relations with other states and noncompliance with the principles of international law and challenging the international order, the possibility to consider the entity in question as a person of international law must be excluded. The personality of the so-called Islamic State is very specific. Over the years 2014-2017, it was a highly complex hybrid terrorist structure characterized by elements typical of a classic terrorist organization, terrorist network, criminal group, armed formation, and a state. 


\section{REFERENCES:}

Antonowicz, L. (2015). Podręcznik prawa międzynarodowego. Warszawa: Wolters Kluwer Polska.

Atwan, A.B. (2015). Islamic State: The Digital Caliphate. London: Saqi Books.

BBC: Państwo Islamskie odradza się w Iraku (2019, December 23). Rzeczpospolita. Retrieved from: https://www.rp.pl/Konflikty-zbrojne/191229829-BBC-PanstwoIslamskie-odradza-sie-w-Iraku.html.

Bocheńska, J. (2011, August 23). Kurdystan iracki - cierpliwe poszukiwanie wolności. Geopolityka.org. Retrieved from: http://www.geopolityka.org/analizy/joannabochenska-kurdystan-iracki-cierpliwe-poszukiwanie-wolnosci.

Bolechów, B. (2020). Słowa w cieniu mieczy. „Dabiq” i narracja Państwa Islamskiego. Wrocław: Wydawnictwo Uniwersytetu Wrocławskiego.

Brands, H., \& Feaver, P. (2017). Was the Rise of ISIS Inevitable? Survival. Global Politics and Strategy, 59(3), 7-54. DOI: 10.1080/00396338.2017.1325595

Castillo, M., Haddad, M., Martinez M., Almasy, S. (2015, November 16). Paris Suicide Bomber Identified; ISIS Claims Responsibility for 129 Dead. CNN. Retrieved from: http://edition.cnn.com/2015/11/14/world/paris-attacks/index.html.

Cirlig, C.C. (2015, March 17). The International Coalition to Counter ISIL/Da'esh (the "Islamic State"). European Parliamentary Research Service, Briefing Paper for the European Parliament. Retrieved from: https://www.europarl.europa.eu/RegData/ etudes/BRIE/2015/551330/EPRS_BRI(2015)551330_EN.pdf.

Cockburn, P. (2015). Państwo Islamskie. Warszawa: Wydawnictwo Naukowe PWN.

Cockburn, P. (2016, June 17). Isis in Fallujah: Iraqi forces end terrorist group's two-year occupation of city. Independent. Retrieved from: http://www.independent.co.uk/ news/world/middle-east/isis-in-fallujah-iraqi-forces-end-terrorist-groups-twoyear-occupation-of-city-a7088346.html.

Czerep, J. (2015). „Kolonie” Państwa Islamskiego w Libii. In: I. Bil, J. Gajda, \& T. Otłowski (eds.). Wojna $z$ Kalifatem (pp. 75-80). Warszawa: Fundacja Amicus Europae.

De Maeyer, P. (2018, July 31). Ponieśli klęskę w Iraku i w Syrii. Teraz ISIS podbija kolejny kontynent. Aleteia. Retrieved from: https://pl.aleteia.org/2018/07/31/ poniesli-kleske-w-iraku-i-w-syrii-teraz-isis-podbija-kolejny-kontynent.

Desbois, P., \& Nastasie, C. (2019). Fabryka terrorystów: ludobójstwo Jezydów. Tajemnice Państwa Islamskiego. Warszawa: Dialog.

Dobbins, J., \& Jones, S.G. (2017). The End of a Caliphate. Survival. Global Politics and Strategy, 59(3), 55-72. DOI: 10.1080/00396338.2017.1325596.

Dołgow, B. (2014). Rozwój Arabskiej Wiosny: wstępne wnioski. In: R. Potocki, M. Piskorski, \& W. Hładkiewicz (eds.). Fale Tunisami. Kontestacja arabska $w$ latach 2010-2013. Warszawa: Europejskie Centrum Analiz Geopolitycznych.

Dziekan, M., Zdulski, K., \& Bania, R. (2020). Arabska wiosna i świat arabski u progu XXI wieku. Łódź: Wydawnictwo Uniwersytetu Łódzkiego.

El Ghamari, M. (2018). Cool Jihad. Warszawa: Difin.

Fragile States Index 2015. Retrieved from: https://fragilestatesindex.org/. 
Gil, G. (2015). Upadanie państwa w stosunkach międzynarodowych po zimnej wojnie. Lublin: Wydawnictwo UMCS.

Godlewski, P. (2015). Ekonomiczne podstawy siły Państwa Islamskiego. In: I. Bil, J. Gajda, \& T. Otłowski (eds.). Wojna $z$ Kalifatem (pp. 55-61). Warszawa: Fundacja Amicus Europae.

Graban, A., \& Jaroszyńska, M. (2018). Działalność propagandowo-informacyjna Daesh. Warszawa: Wojskowa Akademia Techniczna.

Hall, B. (2015). ISIS Państwo Islamskie. Brutalne początki armii terrorystów. Warszawa: Wydawnictwo MUZA.

Harvey, D. (1989). The Condition of Postmodernity: An Enquiry into the Origins of Cultural Change. Oxford: John Wiley and Sons Ltd.

Henzel, P. (2014, October 20). Państwo Islamskie ma nowych sojuszników. Powstaje potężna siatka terrorystyczna. Onet.wiadomości. Retrieved from: http://wiadomosci. onet.pl/tylko-w-onecie/panstwo-islamskie-ma-nowych-sojusznikow-powstajepotezna-siatka-terrorystyczna/jqtzg.

Hodali, D. \& Metzner, I.D. (2014, December 21). Państwo Islamskie nie pojawiło się znikąad. Zachód nie bez winy. DW. Made for Minds. Retrieved from: http:// www.dw.com/pl/pa\%C5\%84stwo-islamskie-nie-pojawi\%C5\%82o-si\%C4\%99znik\%C4\%85d-zach\%C3\%B3d-nie-bez-winy/a-18144034.

Holbrook, D. (2015). Al-Qaeda and the Rise of ISIS. Survival. Global Politics and Strategy, 57(2), 93-104. DOI: 10.1080/00396338.2015.1026070.

IISS Strategic Comments (2016, March). After Brussels: Understanding and Countering ISIS's Strategy. Retrieved from: https://www.iiss.org/publications/strategiccomments/2016/countering-isis-after-brussels.

Ilkowski, F. (2011). Dynamika rewolucji na Bliskim Wschodzie. In: J. Danecki, \& S. Sulowski (eds.). Bliski Wschód coraz bliżej (pp. 31-55). Warszawa: Dom Wydawniczy ELIPSA.

Iraq - Conflict: The Fall of Saddam Hussein and Occupation of Iraq in 2003 (2012). Stosunki Międzynarodowe. Retrieved from: http://www.stosunkimiedzynarodowe. info/kraj,Irak,problemy,Konflikt.

Iraq Says Fully Recaptured Ramadi from ISIS (2016, February 9). Haaretz. Retrieved from: http://www.haaretz.com/middle-east-news/1.702297.

Iraqi Forces and Militia Seize Most of Baiji Refinery: Officials (2015, October 15). Reuters. Retrieved from: http://www.reuters.com/article/us-mideast-crisis-iraqbaiji-idUSKCNOS91GS20151015.

Iraqi Forces Recapture Government Headquarters in Tikrit from Isis (2015, March 31). The Guardian. Retrieved from: https://www.theguardian.com/world/2015/mar/31/ iraqi-forces-recapture-government-headquarters-in-tikrit-from-isis.

Iraqi Forces Retake Rutbah from ISIS and Eye Fallujah for Next Battle (2016, May 19). The Washington Post. Retrieved from: https://www.washingtonpost.com/world/ iraqi-forces-retake-rutba-from-isis-and-eye-fallujah-for-next-battle/2016/05/19/ 3cb32fad-33fe-43df-acba-0edb27865c91_story.html?utm_term=.62bc31eef66d. 
Irshaid, F. (2015, December 2). Isis, Isil, IS or Daesh? One Group, Many Names. BBC News. Retrieved from: https://www.bbc.com/news/world-middle-east-27994277. Islamic State Caliphate Shrinks by 16 Percent in 2016, IHS Markit Says (2016, October 9). Businesswire. Retrieved from: https://www.businesswire.com/news/ home/20161009005034/en/Islamic-State-Caliphate-Shrinks-16-Percent-2016.

Jarczewska-Romaniuk, A. (2005). Amerykańskie wizje ładu międzynarodowego po zakończeniu zimnej wojny. In: R. Kuźniar (ed.). Porządek międzynarodowy u progu XXI wieku. Wizje - koncepcje - paradygmaty (pp. 227-247). Warszawa: Wydawnictwo Uniwersytetu Warszawskiego.

Jendroszczyk, P. (2020, May 27). ISIS miało nie żyć. Ale się odradza. Rzeczpospolita. Retrieved from: https://www.rp.pl/Daesh/305259905-ISIS-mialo-nie-zyc-Ale-sieodradza.html.

Kaczmarek, M. (2014). Jaśminowa Rewolucja. In: R. Potocki, M. Piskorski, \& W. Hładkiewicz (eds.). Fale Tunisami. Kontestacja arabska $w$ latach 2010-2013 (pp. 24-40). Warszawa: Europejskie Centrum Analiz Geopolitycznych.

Kellner, D. (1998). Globalization and the Postmodern Turn. Retrieved from: https:// pages.gseis.ucla.edu/faculty/kellner/essays/globalizationpostmodernturn.pdf.

Kmiecik, P. (2016, August 20). Media społecznościowe w służbie terrorystów. Nowa Strategia.org.pl. Retrieved from: http://www.nowastrategia.org.pl/media-spolecznosciowe-w-sluzbie-terrorystow/.

Kondrakiewicz, D. (2006). Państwo. In: M. Pietraś (ed.). Międzynarodowe stosunki polityczne (pp. 65-91). Lublin: Wydawnictwo UMCS.

Kremer J.F., \& Müller, B. (eds.). (2014). Cyberspace and International Relations: Theory, Prospects and Challenges. Berlin: Springer.

Kubiak, K. (2005). Wojny, konflikty zbrojne i punkty zapalne na świecie. Warszawa: Wydawnictwo TRIO.

Kubiński, G. (2018). Czarny kolor popkultury: Państwo Islamskie i kultura popularna. Kraków: Nomos.

Kucharczyk, M. (2015, December 6). „Podduszanie” przynosi efekty. Tak kurczy się „państwo” dżihadystów. TVN24. Retrieved from: http://www.tvn24.pl/magazyntvn24/podduszanie-przynosi-efekty-tak-kurczy-sie-panstwo-dzihadystow,16,326.

Manchester Bomber Identified: Latest in Terror Investigation (2017, May 23). CBS News. Retrieved from: http://www.cbsnews.com/news/ariana-grande-concertmanchester-arena-bombing-suspect-salman-abedi-isis-claim/.

Michalik, D. (2014). Potencjały państw zaangażowanych w konflikt syryjski w początkach kryzysu. In: R. Potocki, M. Piskorski, \& W. Hładkiewicz (eds.). Fale Tunisami. Kontestacja arabska w latach 2010-2013. Warszawa: Europejskie Centrum Analiz Geopolitycznych.

Mueller, M.L. (2010). Network and States: The Global Politics of Internet Governance. Cambridge: Massachusetts Institute of Technology.

Nizioł-Celewicz, M. (2006). Terroryzm. In: M. Pietraś (ed.). Międzynarodowe stosunki polityczne (pp. 530-571). Lublin: Wydawnictwo UMCS. 
Olszanecka, N. (2012). Weto Rosji dla sytuacji w Syrii. Stosunki Międzynarodowe. Retrieved from: http://stosunki.pl/?q=content/weto-rosji-dla-sytuacji-w-.syrii.

Otłowski, T. (2015). Armia Kalifatu... In: I. Bil, J. Gajda, \& T. Otłowski (eds.). Wojna $z$ Kalifatem (pp. 62-74). Warszawa: Fundacja Amicus Europae.

Ożarowski, R., \& Grabowski, W. (eds.). (2017). Political Dilemmas of the Arab and Muslim World. Warszawa: Rambler Press.

„Państwo Islamskie” sowicie opłaca swoich bojowników. I nakłada nowe „podatki”. (2015, December 13). TVN24bis. Retrieved from: http://tvn24bis.pl/ze-swiata,75/ panstwo-islamskie-coraz-wiecej-zarabia-na-podatkach,602569.html.

Państwo Islamskie straciło niemal całe terytorium, ale pozostaje groźne. Ma 30 tys. bojowników (2018, August 15). Gazeta.pl. Retrieved from: http://wiadomosci.gazeta. pl/wiadomosci/7,114881,23784366,panstwo-islamskie-stracilo-niemal-cale-terytorium-ale-pozostaje.html.

Pietraś, M. (2015). Przestrzeń badawcza nauki o stosunkach międzynarodowych. Politeja, 36, 65-97. DOI: 10.12797/Politeja.12.2015.36.05.

Polskie MSZ potwierdza: w zamachu w metrze zginął polski obywatel (2016, March 30). TVN24. Retrieved from: http://www.tvn24.pl/wiadomosci-ze-swiata,2/zamachy-wbrukseli-w-metrze-zginal-polski-obywatel,631162.html.

Raport: IS straciło w zeszłym roku prawie ćwierć terytorium (2017, January 19). Interiafakty. Retrieved from: http://fakty.interia.pl/raporty/raport-panstwo-islamskie/ newsy/news-raport-is-stracilo-w-zeszlym-roku-prawie-cwierc-terytorium, nId,2339954.

Rojek, K. (2014). Syria w regionalnym układzie stosunków międzynarodowych. In: J. Marszałek-Kawa, \& J. Piechowiak-Lamparska (eds.). Bliski Wschód w XXI wieku. Polityka - Spoleczeństwo - Zmiana (pp. 140-159). Toruń: Wydawnictwo Adam Marszałek.

Rosenau, J.N., \& Singh, J.P. (eds.). (2002). Information Technologies and Global Politics: The Changing Scope of Power and Governance. New York: State University of New York Press.

Sawiński, K. (2014). Konflikt syryjski: od „kontrolowanego chaosu” do „,wojny IV generacji”. In: R. Potocki, M. Piskorski, \& W. Hładkiewicz (eds.). Fale Tunisami. Kontestacja arabska w latach 2010-2013 (p. 156). Warszawa: Europejskie Centrum Analiz Geopolitycznych.

Scholte, J.A. (1996). Beyond the Buzzword: Towards a Critical Theory of Globalization. In: E. Kofman, \& G. Youngs (eds.). Globalization: Theory and Practice (pp. 43-57). London: Pinter.

Smoleń, K. (2020). Geostrategiczne położenie Turcji w XXI wieku. Lublin: Wydawnictwo UMCS.

Surmacz, B. (2015). Ewolucja wspótczesnej dyplomacji. Aktorzy struktury funkcje. Lublin: Wydawnictwo UMCS.

Szmulik, B., \& Żmigrodzki, M. (2002). Pojęcie, sposoby definiowania oraz cechy państwa. In: B. Szmulik, \& M. Żmigrodzki (eds.). Wprowadzenie do nauki o państwie i polityce (pp. 13-22). Lublin: Wydawnictwo UMCS. 
Tanter, R. (2014). Australia in America's Third Iraq War. The Asia-Pacific Journal, 12(51), 1-24. Retrieved from: https://apjjf.org/-Richard-Tanter/4238/article.pdf.

Warrick, J. (2017). Czarne flagi. Geneza Państwa Islamskiego. Warszawa: Wydawnictwo W.A.B.

Wasiuta, O., Wasiuta, P., \& Mazur, P. (2018). Państwo Islamskie ISIS: nowa twarz ekstremizmu. Warszawa: Difin.

Weiss, M., \& Hassan, H. (2015). Wewnątrz armii terroru. Warszawa: Burda Publishing Polska.

Wejkszner, A. (2018). Samotne wilki kalifatu? Państwo Islamskie i indywidualny terroryzm dżihadystyczny w Europie Zachodniej. Warszawa: Difin.

Wojciechowski, S. (2016). Fenomen „Państwa Islamskiego” i jego źródła. Przegląd Strategiczny, 9, 143-155. DOI: 10.14746/ps.2016.1.11.

Wojtasik, K. (2016). Życie codzienne na terenach tzw. Państwa Islamskiego w przekazie jego oficjalnych mediów. Media i Społeczeństwo, 6, 86-97. 